\title{
Thurber needlegrass: Seasonal defoliation effects on forage quantity and quality
}

\author{
DAVID GANSKOPP
}

Author is range scientist, USDA-Agricultural Research Service, Eastern Oregon Agricultural Research Center, HC-71 4.51 Hwy. 205, Burns, Ore. 97720.

Abstract

Although Thurber needlegrass (Stipa thurberiana Piper) is an important component of Palouse, sagebrush:steppe, and pine:forest rangelands, little is known of its qualitative and quantitative responses to defoliation. At 14-day intervals one of 7 cohorts of Thurber needlegrass plants was defoliated to a $2.5-\mathrm{cm}$ stubble to describe initial growth rates, determine defoliation effects on subsequent regrowth accumulations, relate regrowth potential to available soil moisture, and determine the nutritional value of initial growth and regrowth for livestock. The study was conducted in 1985 and 1986 with a different group of plants used each year. Although crop-year precipitation for the 1985-86 treatment years was 77 and $111 \%$, respectively, of the long term mean $(25.2 \mathrm{~cm})$, growth rates of tussocks were similar between years $(P>0.05)$. Seasonal yield of regrowth varied between years, however, and was well correlated $\left(r^{2}=0.76\right.$ to $\left.0.80 P<0.05\right)$ with soil moisture content when treatments were applied. Among 7 defoliation dates (24 April-17 July) only the first 5 yielded regrowth in 1985, and all produced regrowth in 1986. Among treatments regrowth averaged $22 \%$ of total herbage yield in 1985 and $50 \%$ of total yield in 1986. In both years total herbage accumulations were must suppressed (47-63\% reduction) by defoliation during the early-boot stage of phenology. In 1985 when conditions were drier, any defoliation before mid-June depressed $(P<0.05)$ total herbage yield. Crude protein (CP) of needlegrass herbage was high (19-22\%) when growth began in April but declined $(\mathrm{P}<0.05)$ to marginal levels for cattle (6.7-7.7\%) by mid-July. Regrowth harvested on 31 July ranged from 7 to $9 \%$ CP for the earliest (24 April) treatments and as high as $17 \%$ for the latest (17 July). Although Thurber needlegrass can produce highly nutritious regrowth for late-season use, managers face diminishing levels of regrowth as the initial cropping date is delayed later into the growing season. Managers contemplating 2-crop grazing regimes for Thurber needlegrass should base scheduling on plant phenology, soil moisture considerations and historic use rather than specific calendar dates. Further work is needed, however, to definitively determine Thurber needlegrass responses to long-term manipulative grazing regimes.

Key Words: Stipa thurberiana Piper, herbage production, grazing, livestock nutrition, regrowth, soil moisture, forage conditioning, rangelands

Eastern Oregon Agricultural Research Center, including the Bums and Union Stations, is jointly operated by the Oregon Agr. Exp. Sta. of Oregon State Univ. and the USDA-Agricultural Research Service.

Technical Paper No. 11105 . Oregon Agr. Exp. Sta.

Manuscript accepted 12 JuI. 1997.
Resumen

A pesar de que Thurber needlegrass (Stipa thurberiana Piper) es un importante componente en pastizales de las regiones Palouse, sagebrush steppe, $y$ en bosques de pino, poco se sabre de sus respuestas cualitativas y cuantitativas a la defoliación. Uno de 7 tallos de plantas de Thurber needlegrass fue defoliado a intervalos de catorce días, a una altura de $2.5 \mathrm{~cm}$ para describir indices de crecimiento inicial, determinar los efectos de la defoliación en la acumulación posterior, relacionar el potencial de regeneración con la humedad disponible del suelo, y determinar el valor nutritivo del crecimiento inicial y los rebrotes para el ganada. Este estudio fuel realizado en 1985 y 1986 usando diferentes grupos de plantas cada año. Aunque la precipitación durante el ciclo de crecimiento fue 77 y $111 \%$ respectivamente, de la media anual $(25.2 \mathrm{~cm})$, el indice de crecimiento de las plantas entre años fue similar $(P>\mathbf{0 . 0 5})$. Sin embargo, la regeneración fue diferente entre años, y fue altamente correlacionada $\left(r^{2}=0.76\right.$ a $\left.0.80, P<0.05\right)$ con el contenido de humedad del suelo cuando los tratamientos de defoliación fueron aplicados. Entre las 7 fechas de defoliación ( 24 de Abril - 17 de Julio) solamente las primeras cincu produjeron rebrotes en 1985, y todas produjeron rebrotes en 1986. La regeneración promedio entre tratamientos fue de $22 \%$ de la producción total en 1985 y $50 \%$ de la producción total en 1986. La producción total en ambos años fue mas reducida (reducida entre $47-63 \%$ ) por la defoliación durante la etapa fenológica de elongación. En 1985 bajo condiciones mas secas, cualquier defoliación antes de mediados de Junio redujo (P $<0.05$ ) la producción total. La proteína cruda (CP) del follaje de needlegrass fue alta (19-22\%) cuando el crecimiento inició en Abril, pero declinó $(P<0.05)$ a niveles marginales para el ganado (6.7-7.7\%) a mediados de Julio. Los rebrotes colectados el 31 de Julio variaron entre 7 y $9 \%$ CP para los tratamientos iniciales (24 de Abril) y hasta $17 \%$ para el último tratamiento (17 de Julio). A pesar de que Thurber needlegrass puede producir rebrotes altamente nutritivos para uso a finales de la temporada, los administradores enfrentan niveles de regeneración reducidos conforme se pospone la fecha inicial de defoliación. Los administradores considerando dos ciclos de pastoreo para Thurber needlegrass deben basar sus programas en la fenología de las plantas, las condiciones de humedad del suelo y la historia de uso, en lugar de fechas específicas. Sin embargo, es necesario mas trabajo para determinar definitivamente la respuesta a sistemas de pastoreo a largo plazo de Thurber needlegrass.

The goal of this research was to explore the potential of manipulative grazing to enhance late-season forage quality of Thurber 
needlegrass (Stipa thurberiana Piper). Thurber needlegrass is native to Palouse, sagebrush-steppe, and pine-forest rangelands from northern California northeast into Wyoming and as far north as eastern Washington. In some areas it dominates the herbaceous layer (Hironaka et al. 1983), and in others it is subordinate to bluebunch wheatgrass (Agropyron spicatum (Pursh) Scribn. \& Smith), Idaho fescue (Festuca idahoensis Elmer), or needle-andthread grass (Stipa comata Trin. \& Rupr.) Daubenmire 1970). In drier environments a single season of heavy grazing or severe defoliation of Thurber needlegrass can cause subsequent reductions in annual herbage production, basal area, root mass, and plant height (Ganskopp and Bedell 1981, Eckert and Spencer 1987), and effects are most pronounced when leaf area is removed during the early-boot stage of phenology (Ganskopp 1988). In more mesic environments, where it coexists with bluebunch wheatgrass, a single season of heavy grazing may have no effect on plant vigor (Eckert and Spencer 1987).

Hickman (1975) and Cruz-Guerra (1994) have provided the only nutritional evaluation of Thurber needlegrass in conjunction with several other forages, and both observed that its crude protein (CP) content after mid-growing season remained slightly higher than associated perennial grasses (i.e. bluebunch wheatgrass, Idaho fescue, bottlebrush squirreltail (Sitanion hystrix (Nutt.) Smith), or Junegrass (Koeleria cristata Pers.). By midAugust, however, its CP content was below maintenance requirements for beef cattle (Hickman 1975 and Cruz-Guerra 1994). Past research has suggested that manipulative defoliation of grasses, by either mechanical or animal means, can be used to alter plant phenology and improve forage quality (Hyder and Sneva 1963, Pitt 1986). Recent attempts, however, to demonstrate the potential for forage conditioning have been less conclusive (Westenskow-Wall et al. 1994). This study was initiated because there is no information available on the interactions of seasonal defoliation with forage yield and forage quality of Thurber needlegrass. Specific objectives were to: 1 ) describe the growth and regrowth potentials of seasonally defoliated needlegrass, and 2) determine the seasonal nutritive value of initial growth and regrowth components of Thurber needlegrass as phenology advanced. This was accomplished by progressively defoliating needlegrass cohorts at 2-week intervals during 2 growing seasons, harvesting regrowth after plants had ceased production, and subsequently determining the $\mathrm{CP}$ and neutral detergent fiber (NDF) contents of both components.

\section{Materials and Methods}

Research was conducted at the Northern Great Basin Experimental Range $119^{\circ} 43^{\prime} \mathrm{W}, 43^{\circ} 29^{\prime} \mathrm{N}$ ) about $72-\mathrm{km}$ westsouthwest of Burns, Ore. Mean annual precipitation 1952-1995), arriving primarily as snowfall in winter and spring months, is $28.2 \mathrm{~cm}$; and mean annual temperature is $7.6^{\circ} \mathrm{C}$ with extremes of -29 and $42^{\circ} \mathrm{C}$. Forage growth in the region is typically arrested in mid-July by soil moisture depletion, and herbage yield is most strongly correlated with September-June precipitation (Sneva 1982) which averages $25.2 \mathrm{~cm}$.

In 1982 after range grasses entered quiescence, 150 Thurber needlegrass tussocks were excavated from areas supporting a Wyoming big sagebrush (Artemisia tridentata subsp. wyomingensis Beetle)-Thurber needlegrass community (Doescher et al.
1984; Lentz and Simonson 1986). Tussocks were transplanted to polyethylene bags having a $25-\mathrm{cm}$ diameter and $61-\mathrm{cm}$ depth that had been filled with a sifted alluvium (77\% sand, $9 \%$ silt, and $14 \%$ clay). This medium facilitated recovery of roots, which has been reported elsewhere (Ganskopp 1988). Two samples of the alluvium were retained for development of moisture release curves by Oregon State University's Soil Testing Laboratory. Bags were placed in 61-cm deep trenches and interspaces filled with soil. The $61 \mathrm{~cm}$ planting depth was used because it approached the depth of unweathered bedrock in the plant's natural habitat (Lentz and Simonson 1986). A one-time addition of 2 liters of water was furnished each tussock to facilitate soil:root contact, and plants received no supplemental moisture or fertilization thereafter. Tussocks were allowed 2 growing seasons (1983 and 1984) to establish and acclimate to containers. During those 2 years September-June precipitation was 109 and $119 \%$ of the long-term average.

Fifty-six randomly assigned tussocks were scheduled for treatments in 1985 and the balance retained for replication of the project in $\mathbf{1 9 8 6}$ or as replacements if plant mortality occurred before treatment application. Tussocks scheduled for 1985 treatments were clipped to a $2.5-\mathrm{cm}$ stubble in Oct. 1984 to remove oldgrowth materials, and the 1986 treatments were similarly prepared in the fall of 1985. Each treatment consisted of a single defoliation to a $2.5-\mathrm{cm}$ stubble on one of 7 dates during the growing season. Treatments spanned the vegetative through quiescent stages of growth and were applied at succcssive 14 day intervals beginning 24 April and ending on 17 July each year. The final 17 July treatment was viewed as a control because seed had shattered, nearly all foliage was dry and brown, and little regrowth or impact on plant vigor was expected from defoliation at that time. Plant materials initially harvested in treatment applications were retained and oven dry weights ( 48 hours at $40^{\circ} \mathrm{C}$ ) obtained with an analytical scale to provide a measure of seasonal growth. Concurrent with treatment application, basal areas of plants were determined by measuring major and minor axes of the crowns to the nearest $1 \mathrm{~mm}$ and solving for the area of an ellipse. To compensate for variability in basal area among tussocks, all foliage weights were expressed on a $\mathrm{mg} / \mathrm{cm}^{2}$ basal area basis. Concurrent with treatment application, soil samples (5 to $40-\mathrm{cm})$ were collected from 5 tussocks and soil moisture content derived gravimetrically. Soil sampling at lower depths was attempted but confounded by contamination from the drier and often unstable upper portions of the profile

On 31 July post-treatment regrowth was harvested from all plants. Dried plant materials were ground to pass a $1-\mathrm{mm}$ screen and initial growth and regrowth samples were analyzed for crude protein (AOAC 1980) and neutral detergent fiber (NDF) (Goering and Van Soest (1970).

An experimental unit in this project was an individual tussock. Project arrangement was a completely randomized design with 7 treatments and 8 replications. Response variables included: initial biomass, regrowth biomass, total biomass (sum of initial and regrowth), soil moisture content, and CP and NDF measures of initial growth and regrowth. Completely randomized design analysis of variance was used to test the null hypothescs $\left(\mathrm{H}_{\mathrm{o}}\right)$ of no differences among treatment means, and years were analyzed separately. When significant treatment effects were detected in analyses of variance, mean separations were accomplished with single degree of freedom contrasts. Statistical significance was assumed at $\mathrm{P} \leq 0.05$. 
For each year biomass of initial growth for each treatment (dependent variable) was related to treatment Julian date (independent variable) with regression analyses. The slopes of the resulting equations depict relative growth rates of the needlegrass and allow for comparison of rates between years by testing the null hypothesis that slopes were equal (Neter and Wasserman 1974). Percent soil moisture content for treatment dates (independent variable) was also related via regression analyses to biomass of subsequent regrowth (dependent variable) to develop equations for predicting the regrowth potential of Thurber needlegrass. An F-test was used to compare 1985 and 1986 regression lines (Neter and Wasserman 1974). Finally, crude protein content of regrowth (dependent variable) was related via regression analyses to soil moisture content and biomass of regrowth (independent variables) via regression analyses to assist in graphically illustrating the interactions among these variables.

\section{Results}

\section{Initial Growth Patterns}

Crop-year precipitation for the 1985 and 1986 treatment years was 77 and $111 \%$, respectively, of the long-term average, and plants began producing new growth by mid-April each year. Early growth in 1985 (24 April-22 May) appeared to be slightly ahead of biomass accumulations for the same period in 1986 (Fig. $1 \mathrm{~A}$ and $\mathrm{B}$ ), as no significant change in initial biomass occurred until 5 June in 1986. This was perhaps due to slightly cooler weather in 1986 when mean daily temperatures ((maximum+minimum) $\times 0.5$ ) for 25 April-22 May were $3.7^{\circ} \mathrm{C}$ cooler than the same period in 1985 . Equations relating initial yields of treatments to their corresponding Julian dates for 1985 and 1986 were, respectively,

$y=2.49 \mathrm{Julian}$ date $-251\left(\mathrm{r}^{2}=0.97\right)$ and $2.85 \mathrm{Julian}$ date- $332\left(\mathrm{r}^{2}=0.95\right)$.

Regression lines for these equations are included in Fig. 1A and B. An F-test for comparing the 2 lines revealed no difference $(P>0.05)$ between the equations $(F=3.68$ with $2 \& 10 \mathrm{df}$ ), and a t-test comparing slopes of the 2 equations suggested growth rates were essentially equivalent for the 2 years. When the data were pooled to develop a single model, the equation was: initial biomass $=2.675 \mathrm{Julian}$ date-291 with an $r^{2}$ of 0.93 . In both years growth had nearly ceased by 3 July. Initial growth peaked at $232 \mathrm{mg} / \mathrm{cm}^{2}$ of basal area in 1985 (Fig. 1A) and attained a high of $220 \mathrm{mg} / \mathrm{cm}$ basal area in 1986 (Fig. 1B).

\section{Regrowth and Total Biomass Accumulations}

In 1985 only the first 5 defoliation dates exhibited regrowth (Fig. 1A), with the greatest amount $\left(79 \mathrm{mg} / \mathrm{cm}^{2}\right)$ occurring with the earliest (24 April) defoliation and the smallest produced by plants defoliation on 19 June. Soil moisture content declined to less than $4 \%$ after 19 June. Across all 7 defoliation dates in 1985, regrowth contributions to total biomass averaged $22 \%$. Plants defoliated between 8 May and 5 June averaged about $37 \mathrm{mg} / \mathrm{cm}^{2}$ of regrowth with no difference $(P>0.05)$ among the 3 dates, and no regrowth occurred on plants defoliated in the month of July after seed began to harden. Relative to the 17 July treatment, any defoliation prior to 19 June significantly reduced total herbage accumulation (initial growth + regrowth) for the growing season with the early-boot (8 May) treatment causing the most substantial depression (63\%) in total biomass.

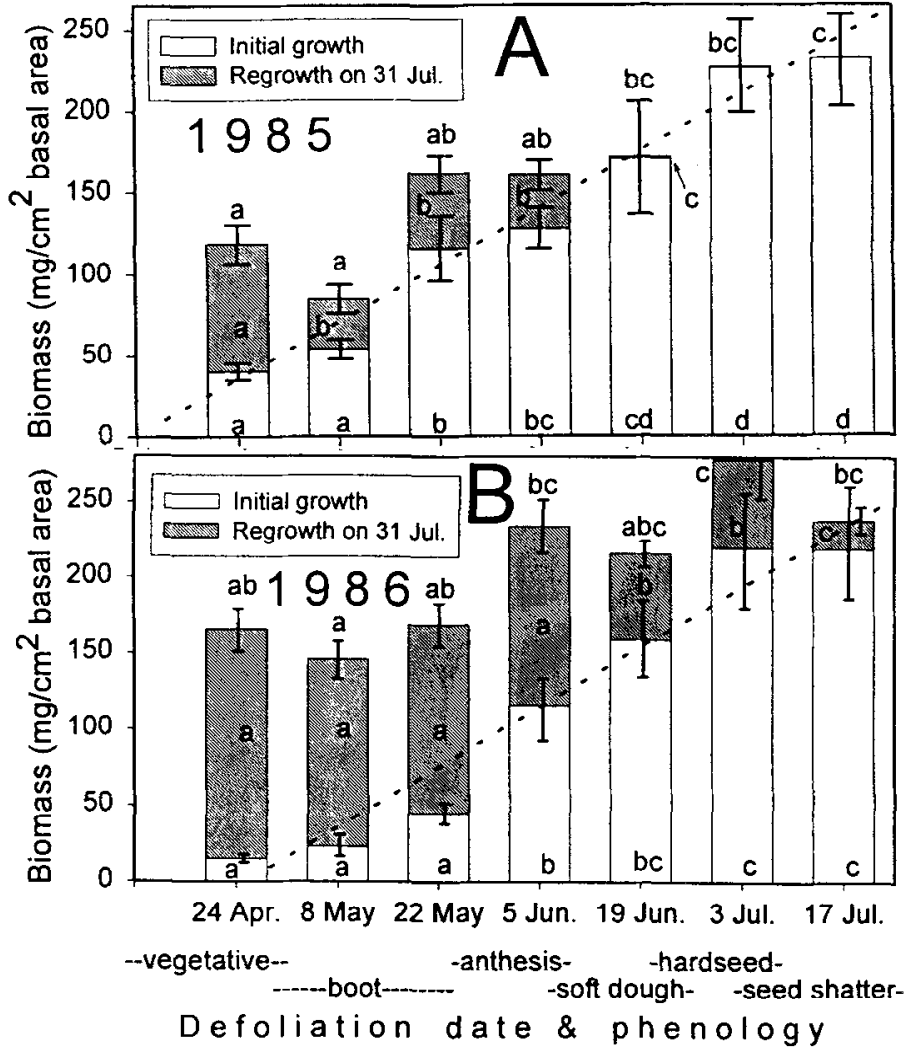

Fig. 1. Biomass of initial growth ( $\pm \mathrm{SE}$ ), regrowth harvested on 31 July ( $\pm \mathrm{SE}$ ), and total herbage yields of Thurber needlegrass tussocks defoliated to a $2.5-\mathrm{cm}$ stubble on 7dates during the 1985 (A) and 1986 (B) growing seasons on the Nortbern Great Basin Experimental Range near Burns, Ore. Dotted lines (-) depict growth rates of needlegrass determined by regressing Julian date of the initial defoliation (independent variable) against initial growth accumulations. Letters at the top of each bar are used for comparison of total herbage yield (initial growth + regrowth) among treatments. Graph components sharing a common letter across dates are not significantly different $(P>0.05)$.

With higher levels of soil moisture in 1986 regrowth occurred in all 7 treatments (Fig. 1B), and across treatments regrowth made a greater contribution $(\bar{x}=50 \%)$ to total biomass than occurred in 1985. Regrowth contributions were roughly equal $\left(\bar{x}=129 \mathrm{mg} / \mathrm{cm}^{2}\right)$ among the first 4 defoliation dates with the first significant $(P<0.05)$ depression in regrowth occurring with the 19 June defoliation. The smallest regrowth accumulation $\left(19 \mathrm{mg} / \mathrm{cm}^{2}\right)$ occurred with the final 17 July treatment. Among treatments peak total herbage production ( $278 \mathrm{mg}$ ) occurred with the 3 July treatment with $21 \%$ of that contributed by regrowth. The lowest level of total herbage accumulated in 1986 again occurred with the early-boot defoliation (8 May, 146 $\mathrm{mg} / \mathrm{cm}^{2}$ ). In that instance total biomass was only $53 \%$ of the 1986 maximum of $278 \mathrm{mg} / \mathrm{cm}^{2}$.

\section{Relationship Between Residual Soil Moisture and Regrowth}

Regression analyses revealed significant $(P<0.01)$ linear relationships existed between soil moisture content on the date of initial defoliation and subsequent accumulations of regrowth during both years (Fig. 2). Because soil moisture was higher in 1986, regrowth rates and amounts across treatments appeared to be higher, and the F-test for comparison of regression lines rejected $(P<0.05)$ the null hypothesis that the 2 models were equivalent $(\mathrm{F}=12.02$ with 2 and $10 \mathrm{df}$. 


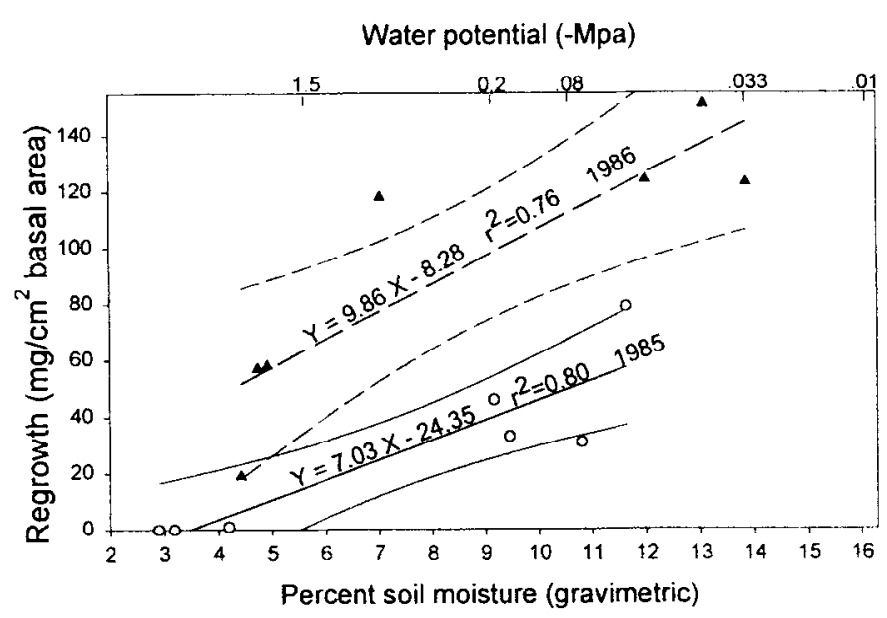

Fig. 2. Linear regressions ( $\pm 95 \%$ CI) relating soil moisture content on the date of initial defoliation to subsequent yields of regrowth harvested on 31 July in 1985 (filled triangles $\Delta$ ) and 1986 (hollow circles $O$ ) from Thurber needlegrass tussocks on the Northern Great Basin Experimental Range near Burns, Ore.

\section{Forage Quality of Initial Growth}

As the growing season advanced, the crude protein content of the initial growth component exhibited a progressive decline (Fig. 3A) typical of cool-season grasses in an arid Mediterranean climate (Raleigh and Lesperance 1972, Hickman 1975, Angell et al. 1990). In 1985, as reproductive portions of the plants developed and matured, CP fell below $7.5 \%$ by early July and then stabilized at about $6.7 \%$ when plants entered quiescence. In 1986 with more moisture available, $\mathrm{CP}$ content of Thurber needlegrass remained above the suggested $7.5 \%$ maintenance level for beef cattle through the mid-July sampling (Fig. 1A). Neutral detergent fiber, a measure of the cell wall components of forages, increased progressively as the needlegrass matured (Fig. 4A). NDF values for initial growth ranged between 40 and $70 \%$ in 1985 and between 46 and $67 \%$ in 1986.

\section{Forage Quality of Regrowth}

Generally, crude protein content of regrowth gave the appearance of being negatively associated with age of the foliage (Fig. 3B). Regrowth of plants defoliated on 24 April 1985 averaged only $7.2 \% \mathrm{CP}$ which was only slightly higher than the $6.8 \%$ value of initial foliage of the final 2 treatments (Fig. 3A). Regrowth of the 22 May and 5 June treatments averaged $11 \% \mathrm{CP}$ in 1985 , but material obtained from subsequent treatments that year was insufficient for chemical analyses. In 1986 the CP content of the 24 April treatment was slightly above minimum maintenance requirements of beef cattle at $8.9 \%$, and the last 2 defoliation dates furnished foliage of nearly $17 \% \mathrm{CP}$.

Regrowth NDF values varied between 50.7 and $67.3 \%$ and appeared to be positively correlated with age of herbage (Fig. 4B). Intuitively, one might expect the youngest regrowth (17 July) to provide NDF values more closely aligned with those of early initial foliage (Fig. 4A), perhaps somewhere in the $40 \%$ range, but since most of the regrowth was also cured foliage when harvested on 31 July, scores were slightly higher than anticipated.
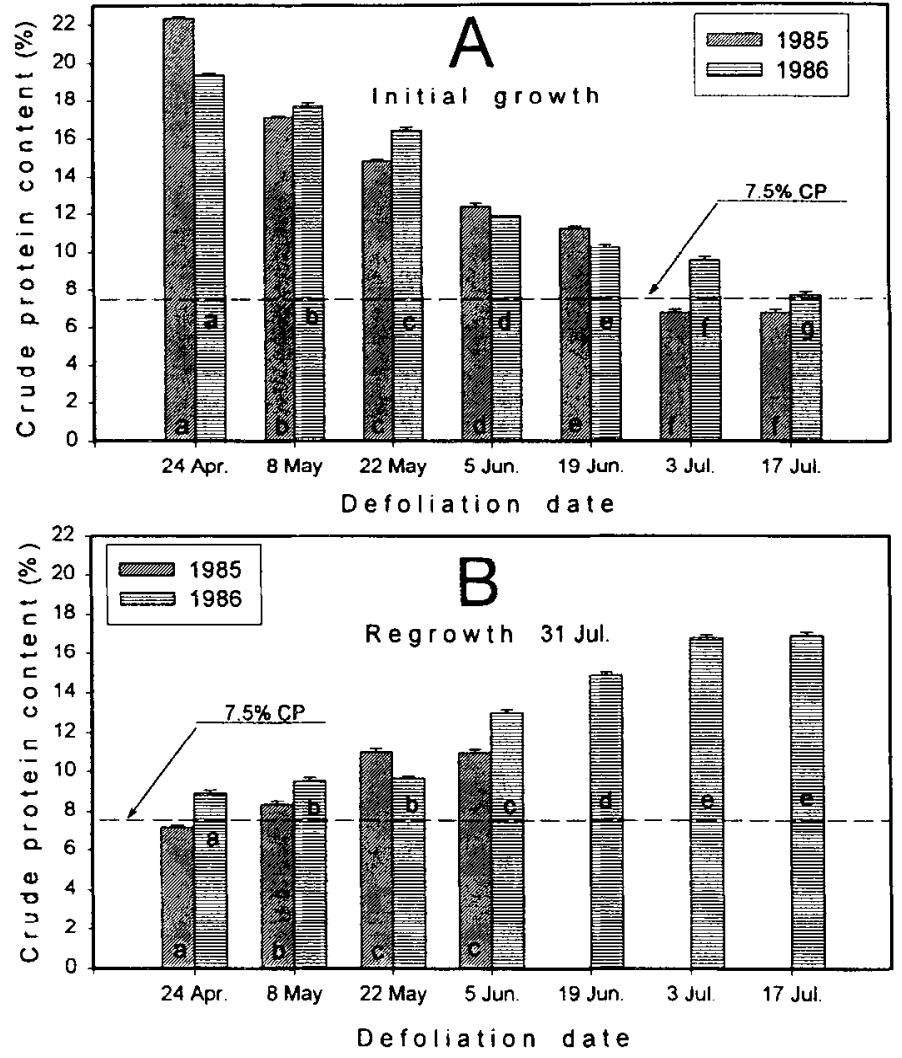

Fig. 3. Crude protein content ( $\pm \mathrm{SE}$ ) of initial growth at 14 day intervals (A) and subsequent regrowth harvested on 31 July (B) from Thurber needlegrass tussocks growing on the Northern Great Basin Experimental Range near Burns, Ore. in 1985 and 1986. Bars within years sharing a common letter are not significantly different $P>0.05$.

\section{Discussion and Conclusions}

Despite substantial differences in crop year precipitation hetween years (77 and $111 \%$ average), rates of initial growth accumulation for Thurber needlegrass were approximately equal for both years. Total herbage accumulations among treatments were higher, however, in 1986 than in 1985 due to greater precipitation and the resulting greater potential for regrowth in 1986 (Fig. 3). Maximum herbage production $\left(232 \mathrm{mg} / \mathrm{cm}^{2}\right)$ in 1985 consisted entirely of initial growth, whereas maximum herbage production $\left(278 \mathrm{mg} / \mathrm{cm}^{2}\right)$ in 1986 contained a $20 \%$ regrowth component. Eckert and Spencer (1987) noted that Thurber needlegrass was more affected by grazing on xeric than mesic sites, and this study suggested that similar responses can be expected when comparing effects between above- and below-average precipitation years on a given site. In both years of study, however, total biomass accumulations were depressed by defoliations on or before $8 \mathrm{May}$. The patterns for both years suggested the 8 May treatment, when Thurber needlegrass was in the early boot stage of phenology, had the greatest impact on total biomass.

Hyder and Sneva (1963) initially proposed a 2-crop grazing program in the region for crested wheatgrass to generate high quality, leafy regrowth for late-season use. Typically the nutrient content of season-long deferred forages falls below the maintenance requirements for cattle by the time the grasses have ceased growth. In both years of this study the CP content of regrowth 

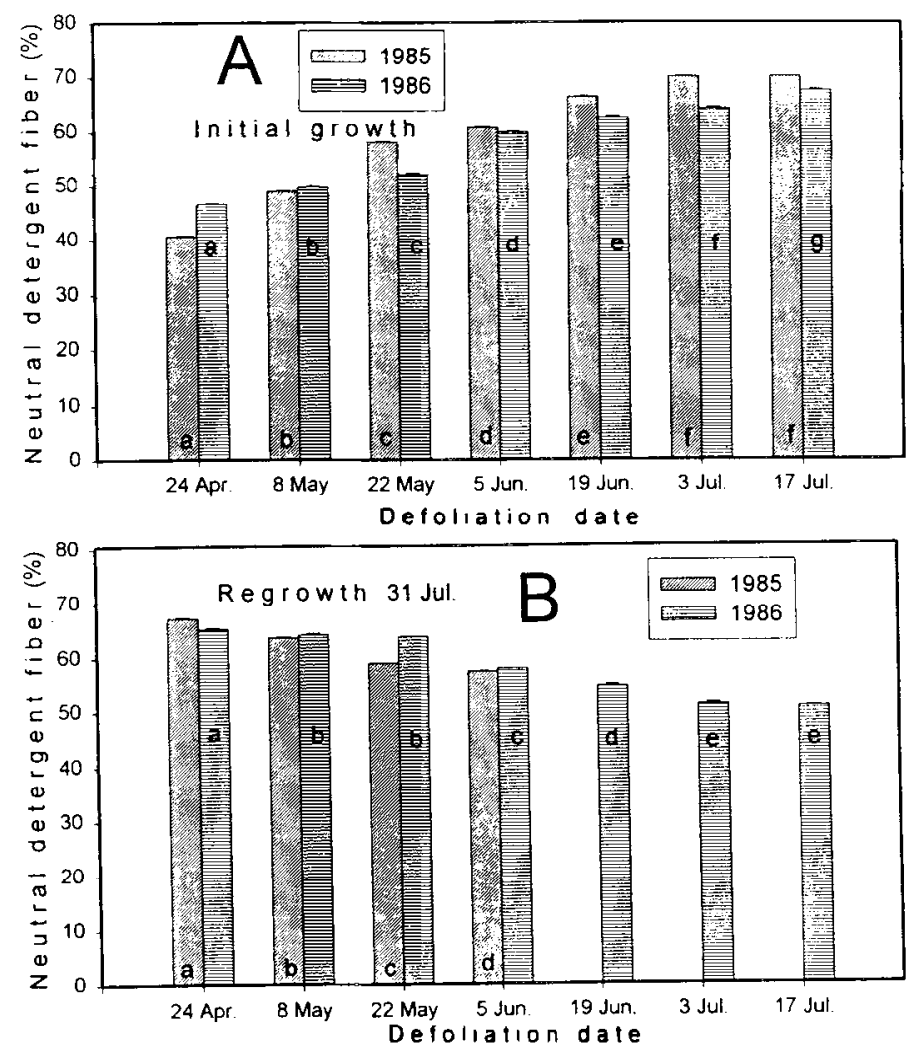

Fig. 4. Neutral detergent fiber content ( \pm SE) of initial growth at 14 day intervals (A) and subsequent regrowth harvested on 31 July (B) from Thurber needlegrass tussocks growing on the Northern Great Basin Experimental Range near Burns, Ore. in 1985 and 1986. Bars within years sharing a common letter are not significantly different $P>0.05$.

generated by Thurber needlegrass initially defoliated on or after 8 May exceeded the needs of beef cattle on 31 July. Regrowth CP content of the latest defoliations was as high as $17 \%$, but one is simultaneously faced with diminishing production of regrowth as the initial defoliation date is postponed and soil moisture levels decline to less than $8 \%$ (Fig. 5). In dry years any attempt at a 2 crop grazing regime may result in less total forage being harvested from a pasture. In wet years a slight gain in total forage harvest might be realized if soil moisture remains available for regrowth late in the growing season. The elevated nutritional value of the regrowth would certainly benefit lactating or growing cattle that typically cease to gain on late-season forages in the region (Raleigh and Lesperance 1972), and other wild herbivores may also be attracted to the less stemmy and more nutritious foliage (Anderson and Scherzinger 1975, Willms et al. 1980, Vavra and Sheehy 1996).

For many livestock managers the real challenge is to design a sustainable grazing program maximizing returns to their operation. This can perhaps be facilitated by multiplying regrowth biomass (Fig. 1) and its corresponding crude protein content (Fig. 3B) to generate an estimate of harvestable crude protein. In both years of this study harvestable crude protein was maximized with the earliest (24 April) defoliation. If the goal is to maintain a maximum number of animals on adequate forage, then grazing Thurber needlegrass when it is vegetative and subsequently returning to graze the cured regrowth will probably serve this pur-

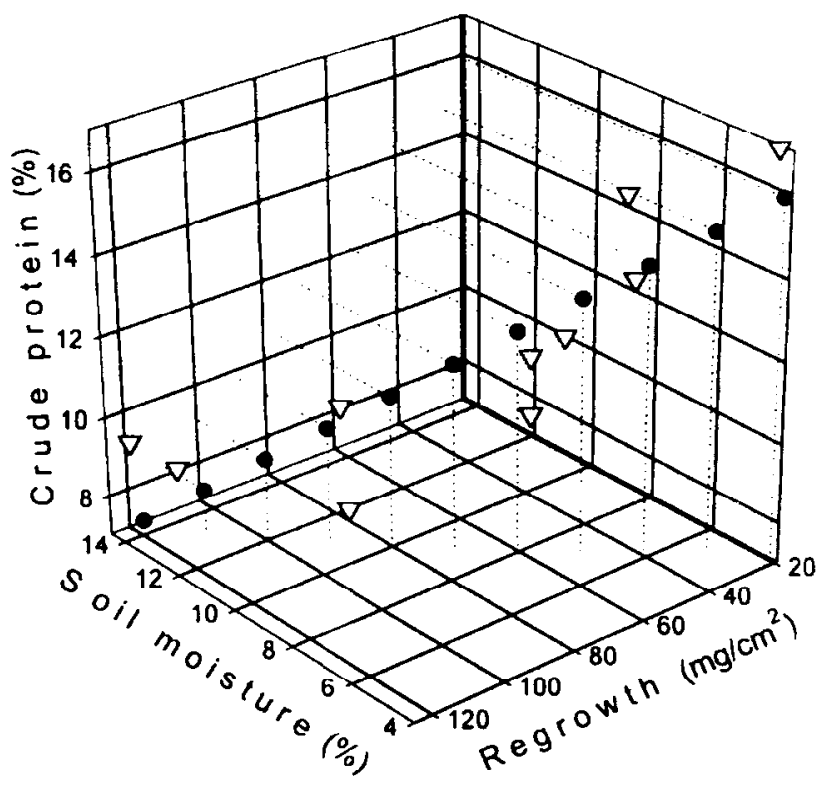

Fig. 5. The interactions among soil moisture content when Thurber needlegrass tussocks were initially defoliated, biomass of subsequent regrowth, and corresponding crude protein content of regrowth harvested on 31 July. Open triangles $(\Delta)$ depict dispersion among treatment means for both years. Filled circles (O) illustrate predicted values derived from regression analyses relating crude protein content of regrowth (dependent variable) to soil moisture content when the plants were initially defoliated and the biomass of subsequently accumulated regrowth (independent variables).

pose. Regrowth from this approach was of marginal quality in 1985 (7.2\% CP), but grazing animals can typically select a higher quality diet than our measures of standing crop suggest, and livestock performance would probably be adequate.

Given the annual variability in climate, growth patterns, and regrowth potentials of Thurber needlegrass, one should base grazing management decisions on plant phenology and knowledge of available soil moisture rather than specific calendar dates. While manipulative cropping of Thurber needlegrass has the potential to stimulate highly nutritious regrowth for livestock or wildlife, the long term effects of intensive 2-crop grazing regimes on Thurber needlegrass have not been evaluated. From a conservative standpoint, any Thurber needlegrass community exposed to a 2-crop grazing program probably should be deferred for at least one growing season afterwards. If grazed during the early-boot stage of phenology, on xeric sites, or under droughty conditions, a longer deferment may be required. A rotation-grazing regime in conjunction with several other pastures would probably provide the greatest potential for management flexibility. Additional studies are needed, however, to further quantify Thurber needlegrass responses to manipulative grazing practices.

\section{Literature Cited}

Anderson, E.W. and R.J. Scherzinger. 1975. Improving quality of winter forage for elk by cattle grazing. J. Range Manage. 28:120-125.

Angell, R.F., R.F. Miller, and M.R. Haferkamp. 1990. Variability of crude protein in crested wheatgrass at defined stages of phenology. $\mathrm{J}$. Range Manage. 43:186-189. 
AOAC. 1980. Official methods of analysis of the Association of Official Analytical Chemists. Washington, D.C. $1018 \mathrm{gp}$.

Cruz-Guerra, R. 1994. Relative palatabilitics of Great Basin forages and mechanisms eliciting selective grazing by cattle. M.S. Thesis, Oregon State Univ., Corvallis, Ore.

Daubenmire, R. 1970. Steppe vegetation of Washington. Washington Agr. Exp. Sta., College of Agr. Washington State Univ. Bull 62.

Doescher, P.S., R.F. Miller, and A.H. Winward. 1984. Soil chemical pattems under eastern Oregon plant communities dominated by big sagebrush. Soil Sci. Soc. Amer. J. 48:656-663.

Eckert, R.E. Jr. and J.S. Spencer. 1987. Growth and reproduction of grasses heavily grazed under rest-rotation management. J. Range Manage. 40:156-159.

Ganskopp, D. 1988. Defoliation of Thurber needlegrass: herbage and root responses. J. Range Manage. 41:472-476.

Ganskopp, D.C. and T.E. Bedell. 1981. An assessment of vigor and production of range grasses following drought. J. Range Manage. $34: 137-141$.

Goering, H.K. and P.J. Van Soest. 1970. Forage fiber analysis (apparatus, reagents, procedures, and some applications). Agr. Handb. No. 379. ARS, USDA. Washington, D.C.

Hickman, O.E. 1975. Seasonal trends in the nutritive content of important range forage species near Silver Lake, Oregon. PNW Forest and Range Exp. Sta. USDA Forest Serv. Res. Pap. PNW-187.

Hironaka, M., M.A. Fosberg, and A.H. Winward. 1983. Sagebrushgrass habitat types of southern Idaho. College of Forest., Wildl., and Range Sci.; Forest. Wildl. and Range Exp. Sta., Univ. of Idaho, Moscow, Ida. Bull. 35.
Hyder, D.N. and F.A. Sneva. 1963. Morphological and physiological factors affecting the grazing management of crested wheatgrass. Crop Sci. 3:267-271.

Lentz, R.D. and G.H. Simonson. 1986. A detailed soils inventory and associated vegetation of Squaw Butte Range Experimental Station. Agr. Exp. Sta. Oregon State Univ., Corvallis, Ore. Special Rep. 760.

Neter, J. and W. Wasserman. 1974. Applied linear statistical models. Richard D. Irwin, Inc. Homewood, III. 842 p.

Pitt, M.D. 1986. Assessment of spring defoliation to improve fall forage quality of bluebunch wheatgrass (Agropyron spicatum). J. Range Manage. 39:175-181.

Raleigh, R.J. and A.L. Lesperance. 1972. Range cattle nutrition. p. 185-199d. In: D.C. Church (ed.) Digestive physiology and nutrition of ruminants. Dept. Anim. Sci. Oregon State Univ., Corvallis, Ore

Sneva, F.A. 1982. Relation of precipitation and temperature with yield of herbaceous plants in eastern Oregon. Int. J. Biometeor. 26:263-276.

Vavra, M. and D.P. Sheey. 1996. Improving elk habitat characteristics with livestock grazing. Rangelands. 18:182-185.

Westenskow-Wall, K.J., W.C. Krueger, L.D. Bryant, and D.R. Thomas. 1994. Nutrient quality of bluebunch wheatgrass regrowth on elk winter range in relation to defoliation. J. Range Manage. 47:240-244.

Willms, W., A.W. Bailey, and A. McLean. 1980. Effect of burning or clipping (Agropyron spicatum) in the autumn on the spring foraging behavior of mule deer and cattle. J. Appl. Ecol. 17:69-84. 